\title{
Grammatical Competence and Pre-Existing Knowledge (Schemata) in Connection with Reading Comprehension
}

\author{
Rizki Amelia, Gunarso Susilohadi, Endang Setyaningsih \\ English Education Department \\ Teacher Training and Education Faculty \\ Sebelas Maret University \\ Email: liaboonunachu@gmail.com
}

Abstract

The aim of the study is to prove empirically the causal relationship between students' grammatical competence, schemata and reading comprehension. correlational study involved thirty students of the eleventh grade students of class science 2 and class science 3 and was conducted in May 2014 at a senior high school in Sragen. The technique of choosing the sample was cluster random sampling. The instruments were multiple choice tests for collecting the three kinds of data including the data of students' grammatical competence, schemata and reading comprehension. Single correlation and multiple linear regressions were used to analyze the data. The result shows that there is a positive correlation between (1) students' grammatical competence and reading comprehension; (2) students' schemata and reading comprehension, and (3) students'grammatical competence and schemata to reading comprehension simultaneously. It means that the improvement of students' grammatical competence and schemata will be in line with the improvement of students' reading comprehension.

Keywords: Grammatical competence, schemata and reading comprehension.

\section{Abstrak}

Tujuan penelitian ini adalah untuk membuktikan secara empiris hubungan kausal antara kemampuan tatabahasa, skemata dan pemahaman bacaan. Penelitian Korelasi ini melibatkan 30 siswa kelas 2 dari kelas Ipa2 dan Ipa3 dan dilaksanakan pada Mei 2014 di sebuah sekolah menengah atas di Sragen.Teknik pemilihan sample dilakukan dengan menggunakan cluster random sampling. Instrumennya meliputi tes-tes pilihan ganda untuk mengumpulkan tiga jenis data yang meliputi data kemampuan tata bahasa, skemata dan pemahaman bacaan. Simple Correlation dan Multiple Regression Correlation Teknik digunakan untuk menganalisa data. Hasil penelitian menunjukkan bahwa terdapat hubungan positif antara: (1) kemampuan tata bahasa and pemahaman bacaan, (2)skemata dengan pemahaman bacaan (3) kemampuan tata bahasa dan skemata dengan pemahaman bacaan. Hal ini berarti bahwa meningkatnya kompetensi tata bahasa dan skemata siswa akan diikuti oleh meningkatnya pemahaman bacaan siswa.

Kata kunci: kompetensi tata bahasa, skemata dan pemahaman bacaan. 
Reading comprehension as the goal of reading could be the indicator of successful reading considering the importance of reading as a skill that stands in most of language learning. Reading comprehension is supported by several contributive factors named grammatical competence and schemata. In other words, reading comprehension can be achieved by having a good grammatical competence and extensive schemata applied in the text.

Reading comprehension is viewed from different perspectives. Viewed from the process, McNamara (2007) wrote, "reading comprehension is the interpretation of the information in the text, the use of prior knowledge to interpret this information and, ultimately, the construction of a coherent representation or picture in the reader's mind of what the text is about" (p.28). In line with this, RAND reading study group in Bernhardt (2011) reported, "reading comprehension as the process of simultaneously extracting and constructing meaning through interaction and involvement with written language" (p.7). Besides, Anderson et al in Alshumaimeri (2011) believed, "reading comprehension is viewed as the process of interpreting new information and assimilating this information into memory structures" (p.187). The other perspective of seeing reading is from its contributive factor and the final goal of reading. Paris \& Stahl (2005) emphasized reading definition based on its contributive factors that are considered as intrinsic and extrinsic factor including motivation, experience, interest, skill and text readability. On the other hand, Grellet (1998) believed, "reading comprehension refers to understanding a written text to extract the required information from it as efficiently as possible" (p.128). 
In sum, reading comprehension in this study means one's thought process of constructing idea and extracting the new required information through the interpretation of new required information that is based on their prior knowledge and the assimilation of the information based on needs and purpose to achieve the goals of reading.

Wood and Connelly (2009) pointed out, "impaired knowledge in the level of clause and sentence influence the understanding of the extended text" (p.26). Knowledge in the level of clause and sentence here is the part of grammatical competence. In line with reading, Johnson (2008) said, "reading is the practice of using text to create meaning" (p.3). Meaning of the text is expressed through the connection of words, clause and sentence that is written in the exact order called grammar. Knapp and Watkins (2005) believed, "Grammar remains simply a set of rules for correctness or appropriateness" (p.31). Further, Radford (1997) said, "Grammar is related to the rules that explain about how the words are built and arranged to be a clause or sentences" (p.1). By having competence on grammar, the student is indicated to be able to understand the small part of text that govern the extended meaning."competence itself is indicated as a conscious understanding of a language rules that govern language production" (Ellis in Aebersold and Field, 1997, p.28). Thus, grammatical competence in this study refers to one's ability to produce and use the distinctive grammatical structure of sentence based on his mastery on the knowledge of language rules. 
Stahl and McKeena (2006) reported, "good readers are constantly relating what they are reading to other experiences they have had, other information in the text they have read, and texts previously read" (p.277). Experience, information and text previously read here refer to schemata. This is the second contributive factor of reading comprehension. Further, Stone (2009) believed, "schemata involved in the interactions of text and readers in which there are highly personal connection between text and reader's personal experiences" (p.45). Aebersold and Field (1997) wrote, "schema is background information that readers bring to a text-including the knowledge of habits and beliefs from their own life experiences" (p.8). Besides, Nuttal (1996) said, "schema is useful concept in understanding how we are able to interpret texts" (p.7). Based on the theory, it can be concluded that schemata that is discussed in this study is organized knowledge from the past experiences involving belief and habit that are used as a framework in making sense of information.

In terms of reading comprehension, students have to activate the appropriate background knowledge or schemata about the text in order to get a deeper understanding. Moreillon (2007) claimed, "readers need the support of schemas as they encounter new ideas and information" (p.21). In line with this Nuttal (1996) said "the idea that past experience gives rise to knowledge organized into schemata makes it easy to see that many connections between facts can be left unstated in texts" (p.8). In addition, Aebersold and Field (1997) said,“among the other kind of schema, content schema (knowledge of the world) is the most useful schema for achieving good comprehension" (p.17). That is schemata or background knowledge about the 
topic of text is prominent for reading comprehension. Students who have a lot of background knowledge (schemata) can apply it as an aid to process the new information from the text. It means that one's schemata will contribute to his/her reading comprehension.

Theoretically, grammatical competence and schemata contribute to the successful of reading comprehension. The writer conducted a research to prove the correlational theory among grammatical competence, schemata and reading comprehension. Therefore, the aim of writing this article is to report the result of the study about the correlation between students' grammatical competence, students' schemata and students' reading comprehension.

\section{RESEARCH METHOD}

The research was conducted in May at a senior high school in Sragen. The sample is 30 from the population of the 190 eleventh grade students of science class which were chosen by using cluster random sampling. Cluster random sampling is a way of selecting the representative sample in which the researcher subdivides the population into subgroups called clusters. Then, the researcher randomly selects a sample of clusters, and then randomly select members of the cluster (Godard and Mevile, 2006). The used research method in this research is correlational method. Singh (2007) noted, "correlation is defined as one of the most widely used measure of association between two or more variables" (p.146). In this study, the variables are: grammatical competence, schemata and reading comprehension. That is, 
Grammatical competence and schemata are the response variables and reading comprehension is the criterion variable.

The instruments which are used to collect the data are in the forms of multiple choice tests. The grammatical competence test consists of 42 questions. It is designed in the scope of grammatical point stated in syllabus. While, the test of schemata consists of 54 questions and it is designed to activate the students' background knowledge of everything that is related to the topic of text. The test of schemata is related to the text that is used in the test of reading comprehension. The reading comprehension test consists of 6 texts with 48 questions. The used text stated in reading syllabus as the types of text that should be taught in the tenth and eleventh grade senior high school students.

The three kinds of data; the data of students' grammatical competence, the data of the students' schemata and the data of the students' reading comprehension are analyzed by using Product Moment and Multiple Linear Regression. Product Formula is used to test the first and the second hypotheses which say that there is a positive correlation between grammatical competence and reading comprehension, and there is a positive correlation between schemata and reading comprehension. Multiple linear correlation is used to test the third hypothesis which says that there is a positive correlation between grammatical competence and schemata toward reading comprehension. 


\section{RESEARCH RESULT AND DISCUSSION}

Based on the testing of the first hypothesis, it is known that the first hypothesis, saying that there is a positive correlation between grammatical competence and reading comprehension is accepted. The computation result shows that the correlation coefficient $\left(\mathrm{r}_{\mathrm{x} 1 \mathrm{y}}\right)$ between $\mathrm{X}_{1}$ and $\mathrm{Y}$ is 0.64305 . Then, it is consulted to the $t$-value. It shows that the value of $t_{o}\left(t_{\text {obtained }}\right)$ is 4.443 . After being consulted to $t_{t}(1.7)$, the result shows that $t_{o}$ (4.443) is higher than $t_{t}(1.7)$ or $t_{o}>t_{t}$. It also means that the correlation between grammatical competence and reading comprehension is significant. The coefficient determination $\left(\mathrm{r}^{2}\right)$ between grammatical competence toward reading comprehension is 0.4135 meaning that $41.35 \%$ variation of reading comprehension is determined by grammatical competence and 58,65 variation of reading comprehension is determined by other factors. In other words, based on this research, the theory about the correlation between students' grammatical competence and reading comprehension is proved.

The result of this study means that the students' grammatical competence helps the students to comprehend the text. It is in line with a study conducted by Akbari (2014). In his study, grammar contributes reading comprehension as grammar allows the readers to have detailed comprehension, deepen their understanding and improve their reading fluency. In line with this, Grabe (2009) believed grammar provides the readers with a signal to clear ideas. By having grammatical competence,

the students will aware of the signal provided by a certain grammatical point that is used in the text. Besides, a report by Connelly and Wood (2009) also asserted that 
struggle reader get difficulty in using cohesive marker to understand the text meaning. Thus, a good competence on grammar will enable the students to use cohesive marker that enable them to see the link of ideas and its transition. Therefore, they will get a better understanding of ideas through their awareness of the signal provided by grammar.

Grammar also facilitates the readers to recover the meaning of text. Thornburry (1999) pointed out, "grammar communicates meaning- meanings of a very precise kind" (p.3). All words that have been written in the text are produced with the grammar inside it. Those words connect each other to build the meaning of the text or information. In relation with this, lack of words meaning may bother the text understanding. If the readers cannot tackle this problem, reading activity seem tedious and sometimes it will decrease their motivation to read more. In this case, competence on grammar enables the readers to recover meaning of the difficult words through the connection of each surroundings words in the text. The readers will aware of the contextual clues of the connection among clause or sentences and the meaning of difficult words can be known from it. In other words, they can use their knowledge of grammar to overcome unknown words based on the context where it occurs.

Knowledge of grammar helps the readers to develop their reading skill so that it will help them to comprehend faster. Williams (1996) stated, "reading is a process whereby one looks at and understands what has been written" (p.2). That is, understanding is a goal of reading. It also means that during reading, the readers have to understand all the part of the text including understand the main idea and 
supporting detail of each paragraph and in terms of reading comprehension they also have to understand the implicit one. In relation with this, Simanjuntak (1988) wrote a line between the students ability in using linguistic knowledge and their skill in reading. Based on her explanation, reading skill is divided into some level including word level, sentence level and paragraph level. Those skills are intended to get comprehension. In other words, the students' grammatical competence facilitates them to be able to apply reading skills in order to understand main idea, implicit information, supporting facts and details.

The result of this study also implies that teaching reading cannot be separated from teaching grammar and vice versa. It is agree with a study conducted by Desta,Tedla, Rothstain and Harris (2014). They reported a successful model of integrating teaching grammar with teaching reading. Based on their study, using reading to enhance students' grammatical competence is said to be more effective than teaching grammar indirectly.

In sum, the students' grammatical competence helps them to understand the text meaning. It also helps to develop reading skill and recover meaning of each word and sentence so that there will no burden in understanding idea on each paragraph. In other words, as the students have grammatical competence, there will be no burden in getting reading comprehension.

From the testing of the second hypothesis which claims that there is a positive correlation between schemata and reading comprehension. It is proved that the second hypothesis is accepted. The result of the computation shows that the 
correlation coefficient $\left(\mathrm{r}_{\mathrm{x} 2 \mathrm{y}}\right)$ between $\mathrm{X}_{2}$ and $\mathrm{Y}$ is 0.60121 . After being consulted to the $t$-value, the value of $t_{o}\left(t_{\text {obtained }}\right)$ is 3.981. Because $t_{o}(3.981)$ is higher than $t_{t}(1.7)$ or $t_{0}>t_{t}$, it can be said that it is significant. Further, it is known that the coefficient determination $\left(\mathrm{r}^{2}\right)$ between schemata toward reading comprehension is 0.3615 . It means that $36.15 \%$ variation of reading comprehension is determined by schemata and 63.85 variation of reading comprehension is determined by other factors. Thus, based on the result of this research, the theory which states that there is a correlation between schemata and reading comprehension is proved.

An extensive content schema indicates a good reading comprehension. Pearson and Rumelhart in Ogle and Blacowich (2008) asserted, "Our knowledge and experiences, as well as our present context, influence how we understand, value and remember what we read"(p.28). In line with this, Nunan (1998) reported that readers' background knowledge and their experience strongly determines comprehension. As the students have an enough prior knowledge of the text, they will understand the information accurately. In other words, their content schema also guides them to avoid misinterpretation of the text meaning. Brown (2004) emphasized the contribution of content schema to prepare the reader with prior expectation about the text so that they will read with a direction. The direction of their reading shape the students thinking process for not to process information out of domain.

A study on the similar topic also shows that content schema give a positive effect on the readers' motivation (a study conducted by Rezaei, Barati and Youhanee ; 2012). It increases the students' motivation on reading as the students read by their 
own experience. Further, read with experience result in the construction of imagination and picture represented information during reading that is termed "situation model" (Grabe, 2006). This situation model leads the reader to illustrate information clearly since it is build from the existing information that is activated to some extent. By applying schemata or background knowledge during reading, the students' brain is busy visualizing the information. They will engage in the text. It is in line with Scott and Stevens' idea that reading needs attention (2005). This attention is the reader's concentration in processing the information. Without schemata, the reader needs an extra effort to keep their attention as they start reading without any preparation of background information so that reading seems difficult.

The study entitled the role of schema for effective EFL reading comprehension that is conducted by Khanam, Zahid and Mondol (2014) found that schema develop the students ability in predicting the information. According to this study, making prediction means to build a psychological schema based on the information of the reading material. Prediction will be more accurate since the existing knowledge help the students to predict based on the existence information

To sum up, students are ready to process any information firmly by applying appropriate schemata about the topic of text. The benefits of content schemata towards reading help the students to comprehend the text and therefore the application of content schemata should be more highlighted on reading.

The third hypothesis which claims that there is a positive correlation between grammatical competence and schemata simultaneously to reading comprehension is 
accepted. It is proven by the computation. It presents that the coefficient multiple correlation $\left(\mathrm{R}_{0}\right)$ is 0.8052 . After being calculated to the $\mathrm{F}$-value, the value of $\mathrm{F}_{\mathrm{o}}(\mathrm{F}$ obtained $)$ is 24.893 and the value of $F_{t}\left(F_{\text {table }}\right)$ is 3.35 . Because $F_{o}(24.893)$ is higher than $F_{t(2,27)}(3.35)$ or $F_{o}>F_{t}$, the coefficient multiple correlation ( $R$ ) can be said as significant. The result of coefficient determination $\left(\mathrm{r}^{2}\right)$ is also obtained. The coefficient determination is 0.6484 meaning that $64.84 \%$ variance of reading comprehension is depend on grammatical competence and schemata and the $35.16 \%$ variation of reading comprehension is determined by the other factors.

The result of computation agreed to the expected hypotheses. This is why to say that a positive correlation between grammatical competence, schemata and reading comprehension of the second grade students of a senior high school in Sragen in the academic year 2013/2014 is significant. Further, it can be drawn that the improvement of grammatical competence and schemata will be in line with the improvement of reading comprehension. The higher level students' grammatical competence and the extensive students' schemata show the higher level students' reading comprehension.

As stated before, grammar contributes to reading significantly. Through grammar, students can understand the meaning of text clearly. Thornburry (2002) noted another feature of grammar that should follow the application of grammar. This feature of grammar is meaning-making potential. That is, grammar also considers the lexical choice that make meaning acceptable based on the context. In other side, Grabe (2006) noted an explanation of text that brings some component of linguistic 
system contributing to comprehension. That is to say, students' competence on grammar enables them to acquire words, sentence, paragraph and how the meaning is organized neatly based on the correctness and appropriateness.

Having a good grammatical competence is not enough to get reading comprehension. Based on the study, $41.35 \%$ variation of reading comprehension is determined by grammatical competence. So that, there is another factor contributed to reading comprehension. In this case, Students also need schemata to process information of text better. Based on this study, schemata contribute $36.15 \%$ variation of reading comprehension. Students who have experience or a prior knowledge about the text should be more ready than students who have not. Schemata or prior understanding about the text will help the students to predict and digest information based on previous related information. Finally, it will ease the students to comprehend text.

\section{CONCLUSION AND SUGGESTION}

From the result of the research, the conclusions that can be drawn are students' grammatical competence has a positive correlation and contribution to their reading comprehension, students' schemata also has a positive correlation and contribution to their reading comprehension and the last, students' grammatical competence and schemata simultaneously, have a positive correlation and contribution to their reading comprehension. Hence, as the implication of this study, the teacher should provide

the students with prior knowledge in teaching reading by applying brainstorming activity. Besides, teacher should help the students to improve their grammatical 
competence through reading. The teacher can induce grammar during teaching reading. Appropriate grammatical point can be thought directly from the text itself. The teacher should create creative and provide the students with comprehensible input and fun learning.

\section{REFERENCES}

Aebersold, J. \& Field, M. (1997). From Reader to Reading Teacher. USA :Cambridge University Press.

Akbari, Z. (2014). The Role of Grammar in Second Language Reading Comprehension: Iranian ESP Context. Procedia-Social and Behavioral Science, 98, 122-126. doi: 10.1016/j.sbspro.2014.03.397.

Alshumaimeri, Y. (2011). The Effect of Reading Method on the Comprehension Performance of Saudi EFL Students. Journal of Elementary Education, 4(1), 185-195.Retrieved from http://www.iejee.com/412011/11IEJEE 41Alshumaimeri.pdf.

Bernhardt, E. B. (2011). Understanding Advanced Second-Language Reading. New York : Routledge.

Blachowicz, C. \& Ogle, D. (2008). Reading Comprehension: Strategies for Independent Learners. London: The Guilford Press.

Brown, H.D. (2004). Language Assessment: Principles and Classroom Practices. USA : Longman Pearson Education, Inc.

Goddard, W. \& Melville, S. (2006). Research Methodology: An Introduction. Juta\&Co, Ltd.

Grabe, W. 2009.Reading in a Second Language: Moving from Theory to Practice.Cambridge University Press: New York.

Grellet, F. 1998. Developing Reading Skill. Cambridge: Cambridge University press.

Harris, Y.R \& Rothstein, S.E. (2014) .Exploring story grammar structure in the book reading interactions of African American mothers and their pre-school 
children:a pilot investigation. Frontiers in Psychology, 5, 545, doi: 10.3389/fpsyg.2014.00545.

Johnson, A.P. (2008). Teaching Reading and Writing: A Guidebook for Tutoring and Remediating Students. New York : Rowman \& Littlefield Education.

Khanam, S, Zahid, S.H \& Mondol, S .(2014). The Role of Schema for Effective EFL Reading Comprehension. ASA University Review, 8,1.

Knapp, P.\& Watkins, M. 2005.Genre,Text,Grammar.Sydney.A UNSW Press.

Moreilon, J. (2007). Collaborative Strategies for Teaching Reading Comprehension: Maximizing Your Impact. Chicago: Harpercollins.

McNamara, D.S. (Eds).(2007). Reading Comprehension Strategies: Theories, Interventions and Technologies. New York : Lawrence Erlbaum Associates.

Nunnan, D. (1998). Language Teaching Methodology. London : Prentice Hall.

Nuttal, C. (1996). Teaching Reading Skills in a Foreign Language. Oxford: The Bath Press.

Paris, S.G. \& Stahl, S.A.(Eds).(2005). Children's Reading Comprehension and Assessment. London : Lawrence Erlbaum Associates Publishers.

Radford, A. (1997). Syntactic Theory and the Structure of English: Minimalist Approach. New York : Cambridge University Press.

Rajabi, P., Rezaei, N. \& Afshari, H. (2013). The Impact of Explicit vs Implicit Compensation Strategy Training on Iranian EFL Students' Reading Comprehension Performance. International Research Journal of Applied and Basic Sciences, 7(12),869-874.

Rezaei, O., Barati, H.\& Youhanee, M.(2012). The Effect of Content Familiarity \& Test Format on Iranian EFL Test Takers' Performance on Test of Reading Comprehension. International Journal of Applied Linguistics \& English Literature, 1(4), 2200-3592, doi:10.7575/ijalel.v.1n.4p.1.

Singh, K (2007). Quantitative Social Research Method. London : Sage Publication.

Simanjuntak, E.G.1988.Developing Reading Skills for EFL Students.Jakarta:P2LPTK 
Stahl, K.A.D. \& McKenna, M. (2006a). Reading Reasearch at Work: Foundations of Effective Practice. In Anderson, R., Wang, Q., Gaffney, J.(Eds). Comprehension Research over the Past Three Decades (pp.276). New York : The Guilford Press.

Stone, R. (2009). Best Practices for Teaching Reading: What Award-Winning Classroom Teachers do. USA : Corwin Press.

Tedla, Y.G \& Desta, M.T. (2014). Reading Stories to Enhance Grammar Intake : Correlational Analysis. International Journal of English Language \& Translation Studies, 2(2),92-105.Retrieved from http://www.eltsjournal.org.

Thornburry, S. (2005). How to Teach Grammar. Essex : Longman.

Williams, E. (1996). Reading in the Language Classroom. London : MacMillan Publishers, Ltd.

Wood, C. \& Connelly, V. (Eds). (2009). Contemporary Perspectives on Reading and Spelling. USA : Routledge. 